\title{
Sistem Pendukung Keputusan Kelayakan Klaim Asuransi Menggunakan Metode AHP
}

\author{
${ }^{1}$ Abdullah Izzul Islam, ${ }^{2}$ Asep Jamaludin, ${ }^{3}$ Nono Heryana \\ Program Studi Teknik Informatika Fakultas Ilmu Komputer Universitas Singaperbangsa Karawang \\ 19abdullah.16006@student.unsika.ac.id, ${ }^{2}$ asep.jamaludin@staff.unsika.ac.id, ${ }^{3}$ nono@staff.unsika.ac.id
}

\begin{abstract}
Abstrak
Pertumbuhan asuransi di Indonesia belakangan ini mengalami peningkatan yang cukup baik hal ini dibuktikan pada statistik pelaku IKNB (Industri Keuangan NonBank) yang diterbitkan oleh OJK (Otoritas Jasa Keuangan) pada Februari 2020. Pada desember 2018 jumlah pelaku IKNB berjumlah 1260 lalu mengalami kenaikan setiap bulannya hingga pada desember 2019 pelaku IKNB berjumlah 1330. Dari data tersebut pelaku IKNB mengalami peningkatan yang cukup baik, dimana asuransi termasuk dalam industri tersebut. Dengan banyaknya pelaku IKNB tersebut PT. SICO Andalan Utama yang merupakan salah satu perusahaan yang bergerak dalam industri tersebut merasakan hal peningkatan hal tersebut. Namun dengan peningkatan tersebut dibutuhkan pengelolaan asuransi terkhusus pengelolaan klaim karena butuh kehati-hatian dalam memutuskan keputusan kelayakan klaim. Maka untuk mengatasi permasalahan tersebut hal inilah yang mendasari penulis untuk mengusulkan pengembangan Sistem Pendukung Keputusan Kelayakan Klaim Asuransi yang nantinya diahrapkan dapat menghindari atau minimal mengurangi ketidak akuratan dalam menentukan kelayakan klaim. Sistem Pendukung Keputusan Kelayakan Klaim Asuransi ini dikembangkan dengan metodologi pengembangan sistem Rapid Application Development (RAD) sebagai alur dari pengembangan sistem. Sedangkan untuk pemodelan SPK nya menggunakan model Analytical Hierarchy Process (AHP). Dan juga menggunakan beberapa tools Unified Modelling Language (UML), Business Process Modelling Nation (BPMN), dan Entity Relationship Diagram (ERD) untuk analisis maupun perancangannya. Dalam pengimplementasian sistem penulis menggunakan PHP sebagai Bahasa pemrograman dan MySQL sebagai Database. Metode pengujian menggunakan metode pendekatan White Box Testing, Black Box Testing Serta Usability Testing. Dengan diterapkan system ini diharapkan dapat memberikan keputusan kelayakan klaim yang tepat.
\end{abstract}

Kata kunci : SPK, AHP, klaim asuransi, rapid application development (RAD), usability testing.

\section{Pendahuluan}

Pertumbuhan asuransi di Indonesia belakangan ini mengalami peningkatan yang cukup baik hal ini dibuktikan pada statistik pelaku IKNB (Industri Keuangan NonBank) yang diterbitkan oleh OJK (Otoritas Jasa Keuangan) pada Februari 2020. Pada desember 2018 jumlah pelaku IKNB berjumlah 1260 lalu mengalami kenaikan setiap bulannya hingga pada desember 2019 pelaku IKNB berjumlah 1330. Dari data tersebut pelaku IKNB mengalami peningkatan yang cukup baik, bisa disimpulkan bahwa dari Desember 2018 hingga Desember 2019 menunjukan peningkatan jumlah Industri Kuangan NonBank (IKNB) terdiri atas perasuransian, dana pensiun, lembaga pembiayaan, lembaga jasa keuangan khusus, dan lembaga keuangan mikro yang dapat berarti asuransi pun juga mengalami peningkatan dalam dunia industri tersebut. Hal ini menjadi sebuah keuntungan tersendiri bagi pihak perusahaan asuransi yang menyediakan layanan asuransi. Karena semakin luas dan berkembang pasar yang bisa diolah dan dijadikan sasaran penjualan produk yang mereka miliki. Dalam perasuransian banyak sekali produk asuransi salah satunya ialah Surety Bond, Dan pada penelitian ini dibatasi pada produk Surety Bond karena menjadi salah satu produk yang banyak dilakukan transaki di PT. SICO Andalan Utama.

Seiring berkembangnya asuransi dan bertambahnya nasabah yang menggunakan layanan asuransi, namun dari beberapa perusahaan asuransi mengalami kesulitan dalam mengelola asuransi yang dibeli para nasabah, seperti contohnya saat proses verifikasi kelayakan klaim asuransi dari pihak perusahaan merasa kesulitan memverifikasi banyaknya data dari banyak nasabah. Menumpuknya nasabah yang mengajukan klaim juga menghambat berjalannya proses verifikasi dijalankan secara tepat.

Berdasarkan penelitian sebelumnya yang dilaksanakan Dodi Himawan (2019) metode Analytical Hierarchy Process (AHP) merpakan metode yang paling optimal dalam studi kasus sistem pendukung keputusan peminjam yang layak bagi lembaga keuangan. Hal ini ditunjukan pada penelitiannya dalam menganalisisis perbandingan metode AHP, TOPSIS, dan SAW dengan metode 
metode pengujian Euclidean Distance pada tabel 1 sebagai berikut :

Tabel 1. Analisis Euclidean Distance

\begin{tabular}{|c|l|l|l|}
\hline Nasabah & AHP & TOPSIS & \multicolumn{1}{|c|}{ SAW } \\
\hline 1 & 0,339 & 0,953 & 0,999 \\
\hline 2 & 0,182 & 0,059 & 0,585 \\
\hline 3 & 0,124 & 0,006 & 0,434 \\
\hline 4 & 0,123 & 0,004 & 0,674 \\
\hline 5 & 0,231 & 0,910 & 0,719 \\
\hline Rata-rata & 0,1998 & 0,3864 & 0,6822 \\
\hline
\end{tabular}

Berdasarkan hasil rata-rata dari ketiga metode yang digunakan dapat diakatakan bahwa metode AHP merupakan metode yang paling baik dikarnakan memiliki nilai yang mendekati nol.

Permasalahan tentang pengelolaan asuransi terlebih dalam manajemen pengajuan klaim dari nasabah yang layak dengan beberapa kriteria yang menentukan. Berdasarkan permasalahan tersebut maka perlu dirancang sebuah sistem pendukung keputusan yang mampu menganalisis serta menghasilkan sebuah keputusan tentang permasalahan yang ada. Oleh karena itu berdasarkan permasalahan tersebut penulis merancang dan membangun "SISTEM PENDUKUNG KEPUTUSAN KELAYAKAN KLAIM ASURANSI (Studi kasus : PT.SICO Andalan Utama)". Dengan adanya ini diharapan membantu pengguna dalam hal ini pihak perusahaan PT.SICO Andalan Utama.

\section{Landasan Teori}

\subsection{Asuransi}

Menurut Ketentuan Pasal 246 KUHD, Asuransi atau Pertanggungan adalah Perjanjian dengan mana penanggung mengikatkan diri kepada tertanggung dengan menerima premi untuk memberikan penggantian kepadanya karena kerugian, kerusakan atau kehilangan keuntungan yang diharapkan yang mungkin dideritanya akibat dari suatu evenemen (peristiwa tidak pasti).

\subsection{Surety Bond}

Merupakan suatu produk inovatif yang ditawarkan oleh perusahaan asuransi sebagai upaya pengambilalihan potensi resiko kerugian yang mungkin dapat dialami oleh salah satu pihak, umumnya pemilik proyek (bouheer) atas kepercayaan yang diberikan kepada pihak lain (kontraktor) dalam pelaksanaan kontrak pemborongan yang telah disepakati oleh mereka.

\subsection{Sistem Pendukung Keputusan}

Tampubolon dalam Riyandi, et al (2017) memaparkan "Sistem pendukung keputusan merupakan sistem informasi interaktif yang menyediakan informasi, pemodelan dan pemanipulasian data. Sistem itu digunakan untuk membantu pengambilan keputusan dalam situasi semiterstruktur dan situasi yang tidak terstruktur, dimana tidak seorangpun tahu secara pasti bagaimana keputusan seharusnya dibuat" [1].

\subsection{Analytical Hierarchy Process (AHP)}

Metode Analytical Hierarchy Process (AHP) dikembangkan awal tahun 1970-an oleh Dr. Thomas L. Saaty, seorang ahli matematika dari Universitas Pittsburg. AHP pada dasarnya didesain untuk menangkap secara rasional persepsi orang yang berhubungan sangat erat dengan permasalahan tertentu melalui prosedur yang didesain untuk sampai pada suatu skala preferensi di antara berbagai set alternatif.

Menurut Saaty dalam Sasongko, et al (2017) memaparkan bahwa keuntungan yang diperoleh bila seseorang memecahkan masalah dan mengambil keputusan menggunakan AHP pada tabel 2 antara lain:

Tabel 2. Keuntungan Menggunakan AHP

\begin{tabular}{|l|l|}
\hline No & \multicolumn{1}{|c|}{ Keuntungan Menggunakan AHP } \\
\hline 1 & $\begin{array}{l}\text { AHP memberi satu model tunggal yang } \\
\text { mudah dimengerti, luwes untuk } \\
\text { keanekaragam persoalan tak terstruktur. }\end{array}$ \\
\hline 2 & $\begin{array}{l}\text { AHP memadukan ancangan deduktif dan } \\
\text { ancangan berdasarkan sistem dalam } \\
\text { memecahkan persoalan kompleks. }\end{array}$ \\
\hline 3 & $\begin{array}{l}\text { AHP dapat menangani saling } \\
\text { ketergantungan elemen-elemen dalam suatu } \\
\text { sistem dan tak memaksakan pemikirang } \\
\text { linear. }\end{array}$ \\
\hline 4 & $\begin{array}{l}\text { AHP mencerminkan kecenderungan alami } \\
\text { pikiran untuk memilah-milah elemen- } \\
\text { elemen suatu sistem dalam berbagai tingkat } \\
\text { berlainan dan mengelompokkan unsur yang } \\
\text { serupa dalam setiap tingkat. }\end{array}$ \\
\hline 5 & $\begin{array}{l}\text { AHP memberi suatu skala untuk mengukur } \\
\text { hal- hal dan mewujudkan metode penetapan } \\
\text { prioritas. }\end{array}$ \\
\hline 6 & $\begin{array}{l}\text { AHP melacak konsistensi logis dan } \\
\text { pertimbangan-pertimbangan yang } \\
\text { digunakan dalam menggunakan berbagai } \\
\text { prioritas. }\end{array}$ \\
\hline 7 & $\begin{array}{l}\text { AHP menuntun ke suatu taksiran } \\
\text { menyeluruh tentang kebaikan sistem } \\
\text { alternatif. }\end{array}$ \\
\hline 8 & $\begin{array}{l}\text { AHP mempertimbangkan prioritas relatif } \\
\text { dari berbagai faktor sistem dan } \\
\text { memungkinkan organisasi memilih } \\
\text { alternatif terbaik berdasarkan tujuan-tujuan } \\
\text { mereka. }\end{array}$ \\
\hline 9 & $\begin{array}{l}\text { AHP tidak memaksakan konsensus tetapi } \\
\text { mensintesiskan suatu hasil yang } \\
\text { representatif dari berbagai penilaian. }\end{array}$ \\
\hline 10 & $\begin{array}{l}\text { AHP memungkinkan organisasi } \\
\text { memperhalus definisi mereka pada suatu } \\
\text { persoalan dan memperbaiki pertimbangan } \\
\text { pengulangan. }\end{array}$ \\
\hline &
\end{tabular}


Dari berbagai pertimbangan tersebut kemudian dilakukan sintesa untuk menetapkan variabel yang memiliki prioritas tinggi dan berperan untuk mempengaruhi hasil pada sistem tersebut. Menurut Saaty (1993), terdapat tiga prinsip dalam memecahkan persoalan dengan AHP, yaitu prinsip menyusun hirarki (Decomposition), prinsip menentukan prioritas (Comparative Judgement), dan prinsip konsistensi logis (Logical Consistency).

Untuk memecahkan suatu masalah dengan menggunakan metode Analytical Hierarchy Process diperlukan langkah-langkah sebagai berikut:

1. Mendefinisikan permasalahan dan menentukan tujuan.

2. Menyusun masalah kedalam suatu struktur hierarki.

3. Menyusun prioritas untuk tiap elemen masalah.

4. Melakukan pengujian konsistensi terhadap perbandingan antar elemen yang didapat tiap tingkat hierarki dengan matrik perbandingan. Penyimpangan dari konsistensi dinyatakan dalam indeks konsistensi yang didapat dari rumus:

$$
C I=\frac{(\lambda \max -n)}{(n-1)} \text { dan } C R=\frac{C I}{R I}
$$

Dengan keterangan :

$\lambda \max =$ Jumlahkan hasil bagi dengan banyaknya elemen yang ada

$\mathrm{n} \quad=$ Banyaknya elemen

RI $\quad=$ Random Index

Berikut rincian random index pada tabel 3 :

Tabel 3. Random Index

\begin{tabular}{|l|l|l|l|l|l|l|l|c|}
\hline $\mathrm{N}$ & \multicolumn{1}{|c|}{1} & \multicolumn{1}{|c|}{2} & \multicolumn{1}{c}{3} & \multicolumn{1}{c|}{4} & 5 & 6 & 7 & 8 \\
\hline $\mathrm{R} 1$ & 0.00 & 0.00 & 0.58 & 0.90 & 1.12 & 1.24 & 1.32 & 1.41 \\
\hline $\mathrm{N}$ & 9 & 10 & 11 & 12 & 13 & 14 & 15 & \\
\hline $\mathrm{R} 1$ & 1.45 & 1.49 & 1.51 & 1.48 & 1.56 & 1.57 & 1.59 & \\
\hline
\end{tabular}

\section{Metode Penelitian}

Metodologi penelitian yang digunakan dalam pengembangan Sistem Pendukung Keputusan Kelayakan Klaim Asuransi ini adalah Software Development Life Cycle (SDLC) dengan model Rapid Application Development (RAD). Dan tahapantahapannya dapat dilihat pada gambar 1 berikut ini :



Gambar 1. Tahap Pengembangan Sistem

4. Perancangan

\subsection{Gambaran Umum Sistem}

Sistem Pendukung Keputusan Kelayakan Klaim Asuransi di PT. SICO Andalan Utama merupakan sistem penentuan keputusan untuk mempermudah user dalam menentukan siapa yang layak dalam mengajukan klaim asuransi. Sistem ini diperuntukan untuk internal perusahaan PT. SICO Andalan Utama yang mengurusi klaim asuransi seorang nasabah ditentukan dengan metode Analytical Hierarchy Process.

\subsection{Bussiness Modelling}

Pada tahapan bussiness Modelling pekerjaan selanjutnya yang dilakukan adalah analisis proses bisnis dari data transaksi. Dan setelah dilakukan observasi penulis mendapatkan 2 pemodelan bisnis yaitu pemodelan bisnis sistem yang berjalan pada gambar 2 dan pemodelan bisnis sistem yang akan dibangun pada gambar 3 .

a. Pemodelan Bisnis Proses Sistem Berjalan



Gambar 2. BPMN Sistem Berjalan

b. Pemodelan Bisnis Sistem Yang Akan Dibangun

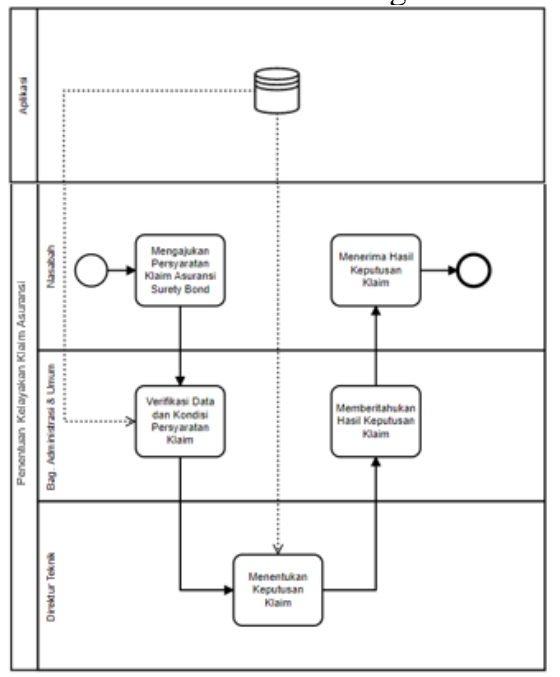

Gambar 3. BPMN Pemodelan Bisnis SPK Klaim Asuransi

4.3 Data Modelling 
Pada tahapan ini penulis mendefinisikan dari tahapan business modeling disaring ke dalam serangkaian objek data yang dibutuhkan untuk menopang bisnis tersebut. Pemodelan data yang dibuat adalah berdasarkan data kebutuhan untuk membangun sistem pendukung keputusan kelayakan klaim asuransi. Berikut diagram pada gambar 4 yang menggambarkan data modelling pada sistem pendukung keputusan ini :



Gambar 4. ERD Sistem Pendukung Keputusan Kelayakan Klaim Asuransi

\subsection{Process Modelling}

Setelah tahapan Bussiness Modelling dan Data Modelling pada tahapan ini selanjutnya membuat alur proses atau Process Modelling yang akan dimodelkan dengan gambar 5 Sequence Diagram sebagai berikut:

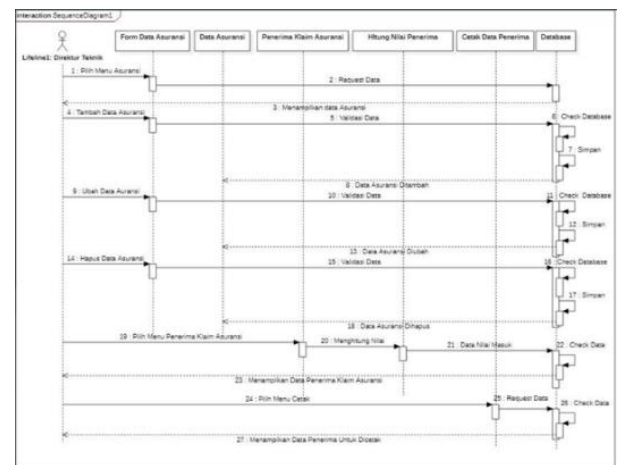

Gambar 5. Sequence Diagram Manajemen Penerima Klaim

Dalam proses ini aktor yang berperan adalah Direktur Teknik. Untuk dapat melakukan perhitungan nilai penerima klaim. Direktur Teknik terlebih dahulu harus masuk ke halaman penerima klaim asuransi. Setelah itu tabel total penilaian perbandingan AHP akan ditampilkan dan diampilkan juga status dari peserta yang lolos menjadi penerima dan yang tidak. Dan dalam proses ini Direktur Teknik juga dapat melakukan CRUD pada data asuransi sebagaimana yang dilakukan oleh aktor umum untuk mengawasi kevalidan data yang dimasukan.

\subsection{Analisis Analytical Hierarchy Process}

Sebelum pengkodean tahapan ini dilakukan untuk mengetahui perhitungan model AHP dalam menentukan Kelayakan Klaim Asuransi. Maka dari itu berikut struktur hierarki model AHP pada gambar 6 dibawah dan penjelasannya.

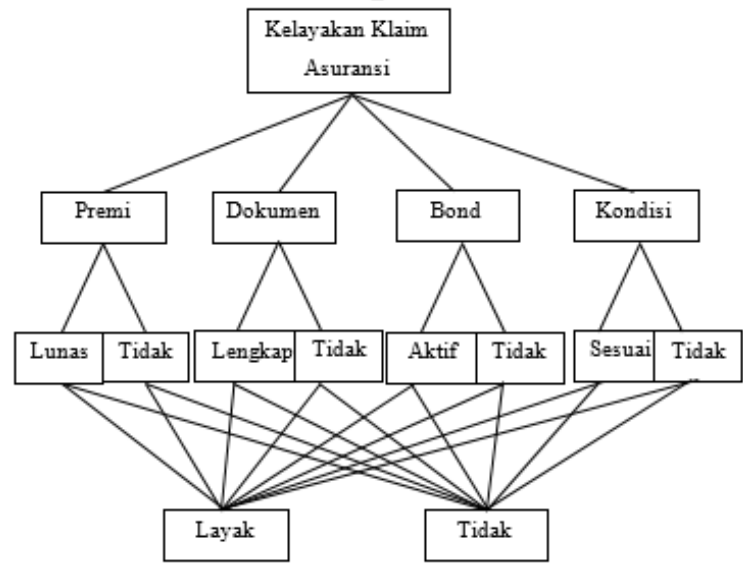

Gambar 6. Struktur Hierarki Model AHP

Ada empat kriteria yang menjadi dasar dari penilaian kelayakan klaim seroang nasabah yaitu :

1. Kelunasan Premi

2. Dokumen-dokumen yang dibutuhkan

3. Bond yang belum kadaluarsa

4. Kondisi proyek sesuai perencanaan.

Tiap kriteria memiliki nilai subkriteria yang berbeda-beda yaitu pada kriteria Premi memiliki nilai subkriteria Lunas dan Tidak Lunas, kriteria Dokumen memiliki subkriteria Lengkap dan Tidak Lengkap, kriteria Bond memiliki subkriteria Aktif dan Tidak Aktif dan kriteria Kondisi memiliki subkriteria Sesuai dan Tidak Sesuai.

Setelah menentukan hierarki struktur model AHP maka selanjutnya melakukan perbandingan berpasangan. Proses ini merupakan penentuan bobot dari tiap kriteria. Berikut salah satu proses dari tujuan yang telah ditentukan:

a) Matriks Perbandingan kriteria

Tabel 4. Matriks Perbandingan kriteria

\begin{tabular}{|c|c|c|c|c|}
\hline Kriteria & Premi & Dokumen & Bond & Kondisi \\
\hline Premi & 1 & 7 & 7 & 7 \\
\hline Dokumen & 0.142857143 & 1 & 5 & 5 \\
\hline Bond & 0.142857143 & 0.2 & 1 & 5 \\
\hline Kondisi & 0.142857143 & 0.2 & 1 & 1 \\
\hline TOTAL & 1.428571429 & 8.4 & 14 & 18 \\
\hline
\end{tabular}

Pada tabel 4 kolom Premi baris Premi menggambarkan tingkat kepentingan yang sama antara kriteria Premi dengan Premi. Premi lebih 
penting jika dibandingkan dengan Masa berlaku Bond, Kondisi Proyek, dan Dokumen. Sedangkan nilai 0,142857143 pada baris Bond kolom Premi merupakan hasil perhitungan $1 /$ nilai pada kolom Bond baris Premi.

b) Penentuan Matriks Nilai Kriteria

Tabel 5. Matriks Nilai Kriteria

\begin{tabular}{|c|c|c|c|c|c|c|}
\hline $\begin{array}{l}\text { Kriter } \\
\text { ia }\end{array}$ & $\begin{array}{l}\text { Pre } \\
\mathrm{mi}\end{array}$ & $\begin{array}{l}\text { Doku } \\
\text { men }\end{array}$ & Bond & $\begin{array}{l}\text { Kondis } \\
\mathrm{i}\end{array}$ & Jumlah & $\begin{array}{l}\text { Priorita } \\
\mathrm{s}\end{array}$ \\
\hline Premi & 0,7 & $\begin{array}{l}0,833 \\
3333\end{array}$ & 0,5 & $\begin{array}{l}0,3888 \\
8889\end{array}$ & $\begin{array}{l}2,4222 \\
2222\end{array}$ & $\begin{array}{l}0,48444 \\
4444\end{array}$ \\
\hline $\begin{array}{l}\text { Doku } \\
\text { men }\end{array}$ & 0,1 & $\begin{array}{l}0,119 \\
0476\end{array}$ & $\begin{array}{l}0,35714 \\
2857\end{array}$ & $\begin{array}{l}0,2777 \\
7778\end{array}$ & $\begin{array}{l}0,8539 \\
6825\end{array}$ & $\begin{array}{l}0,17079 \\
3651\end{array}$ \\
\hline Bond & 0,1 & $\begin{array}{l}0,023 \\
8095\end{array}$ & $\begin{array}{l}0,07142 \\
8571\end{array}$ & $\begin{array}{l}0,2777 \\
7778\end{array}$ & $\begin{array}{l}0,4730 \\
1587\end{array}$ & $\begin{array}{l}0,09460 \\
3175\end{array}$ \\
\hline $\begin{array}{l}\text { Kondi } \\
\text { si }\end{array}$ & 0,1 & $\begin{array}{l}0,023 \\
8095\end{array}$ & $\begin{array}{l}0,07142 \\
8571\end{array}$ & $\begin{array}{l}0,0555 \\
5556\end{array}$ & $\begin{array}{l}0,2507 \\
9365\end{array}$ & $\begin{array}{l}0,05015 \\
873\end{array}$ \\
\hline
\end{tabular}

Nilai 0,7 pada tabel 5 diatas pada kolom Premi baris Premi diperoleh dari nilai perbandingan pada table sebelumnya (nilai 1) yang dibagi dengan jumlah kolom Premi pada table 4 ( 1,428571429). Begitupun dengan nilai-nilai lainnya.

Nilai kolom jumlah diperoleh dan penjumlahan pada setiap barisnya. Untuk baris pertama nilai 2.42222222 merupakan hasil penjumlahan dari $0,7+0,8333333+0,5+$ 0,38888889 .

Nilai pada kolom prioritas diperoleh dari nilai pada kolom jumlah dibagi dengan jumlah kriteria. Dalam hal ini jumlah kriteria adalah 4.

c) Menghitung Konsistensi

1) Penentuan Matriks Penjumlahan Tiap Baris

Tabel 6. Matriks Penjumlahan Tiap Baris

\begin{tabular}{|l|l|l|l|l|l|}
\hline $\begin{array}{l}\text { Kriteri } \\
\mathrm{a}\end{array}$ & Premi & $\begin{array}{l}\text { Dokume } \\
\mathrm{n}\end{array}$ & Bond & Kondisi & Jumlah \\
\hline Premi & 0,48444 & 1,19555 & 0,66222 & 0,35111 & 2,69333 \\
& 4444 & 5556 & 2222 & 1111 & 3333 \\
\hline Doku & 0,06920 & 0,17079 & 0,47301 & 0,25079 & 0,96380 \\
men & 6349 & 3651 & 5873 & 3651 & 9524 \\
\hline Bond & 0,06920 & 0,03415 & 0,09460 & 0,25079 & 0,44876 \\
& 6349 & 873 & 3175 & 3651 & 1905 \\
\hline $\begin{array}{l}\text { Kondi } \\
\text { si }\end{array}$ & 0,06920 & 0,03415 & 0,09460 & 0,05015 & 0,24812 \\
\hline
\end{tabular}

Nilai di atas diperoleh dari perkalian matrik perbandingan pada tabel 4 dengan nilai prioritas pada tabel 5 Misalnya nilai 0,484444444 pada perbandingan kolom dan baris Premi didapat dari nilai prioritas baris Premi pada tabel 5 yaitu 0,484444444 dikalikan dengan nilai perbandingan kolom dari baris Premi pada tabel 4 yaitu 1. Begitu juga dengan nilai-nilai lainnya.

Kolom jumlah pada tabel diatas diperoleh dengan menjumlahkan nilai pada masing-masing baris pada tabel tersebut. Nilai 2,693333333 didapat dari $0,484444444+1,195555556+0,662222222+$ 0,351111111 .

2) Jumlah Baris Dibagi dengan Prioritas

Tabel 7. Jumlah Baris Dibagi dengan Prioritas

\begin{tabular}{|l|l|l|l|}
\hline Kriteria & $\begin{array}{l}\text { Jumlah Per } \\
\text { Baris }\end{array}$ & Prioritas & Hasil \\
\hline Premi & 2,6933333333 & 0,484444444 & 3,177777778 \\
\hline Dokumen & 0,963809524 & 0,170793651 & 1,134603175 \\
\hline Bond & 0,448761905 & 0,094603175 & 0,543365079 \\
\hline Kondisi & 0,248126984 & 0,05015873 & 0,298285714 \\
\hline \multicolumn{3}{|c|}{ TOTAL } & 5,154031746 \\
\hline
\end{tabular}

Kolom jumlah perbaris diambil dari jumlah tiap baris pada tabel 6. Dan Prioritas diambil dari nilai prioritas pada tabel 5 Lalu kolom Jumlah merupakan hasil bagi jumpah perbaris dengan prioritas pada tiap barisnya.

3) Hitung lamda Maksimum ( $\lambda$ maks)

$\lambda$ maks $=\frac{\text { Jumlah Hasil Bagi Jumlah Perbaris dengan Prioritas }}{n \text { (Kriteria })}$

$\lambda$ maks $=\frac{3,177777778+1,134603175+0,543365079+0,298285714}{4}$

$\lambda$ maks $=\frac{5,154031746}{4}$

$\lambda$ maks $=1,288507937$

4) Menghitung Indeks Konsistensi (CI)

$C I=\frac{\lambda \operatorname{maks}-n}{n}$

$C I=\frac{1,288507937-4}{4}$

$C I=\frac{-2,711492063}{4}$

$C I=-0677873016$

Dimana $\mathrm{n}=$ banyaknya elemen

5) $\mathrm{Ss}$

$C R=\frac{C I}{I R}$

$C R=\frac{-0677873016}{0,90}$

$C R=-0,75319224$

Dimana nilai IR diambil dari Daftar Indeks Random Konsistensi yang telah ditentukan nilainya dengan ukuran matriks 4, maka IR bernilai 0,90.

Oleh karena $\mathrm{CR}<0,1$, maka rasio konsistensi dari perhitungan di atas dinyatakan benar.

\section{Implementasi Sistem}

\subsection{Application Generation}

Pada gambar 7 halaman login, menampilkan form Login masuk. Form Login tersedia hanya untuk Umum, Administrasi, Direktur Teknik, dan Direktur.

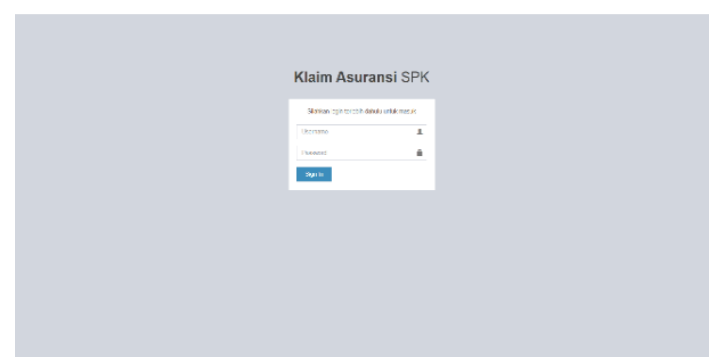

Gambar 7. Antarmuka Login

Pada gambar 8 halaman menu umum, halaman ini akan menampilkan menu ketika Login sebagai Umum yang berisi submenu asuransi. Dimana akses user dapat melakukan manajemen data asuransi (Create, Read, Update dan Delete).



Gambar 8. Antarmuka Halaman Menu Umum 
Pada gambar 9 menampilkan menu ketika Login sebagai Administrasi yang berisi submenu asuransi dan nasabah.

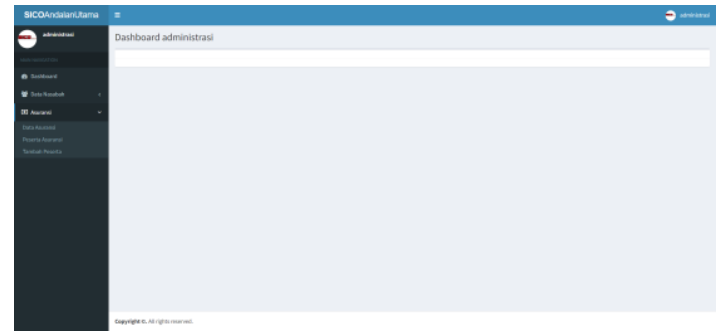

Gambar 9. Antarmuka Halaman Menu Administrasi

Pada gambar 10 menampilkan menu ketika Login sebagai Direktur Teknik yang berisi submenu asuransi, administrasi dan master.

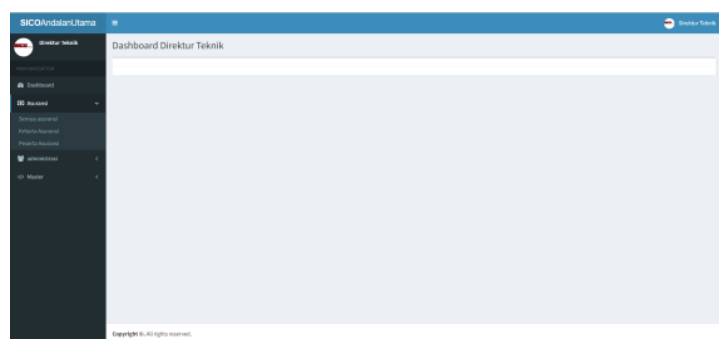

Gambar 10. Antarmuka Halaman Menu Direktur Teknik

Pada gambar 11 halaman ini akan menampilkan menu ketika Login sebagai Direktur yang berisi submenu users. Dimana pada submenu users akses user Direktur dapat melakukan Read dan Delete data user.

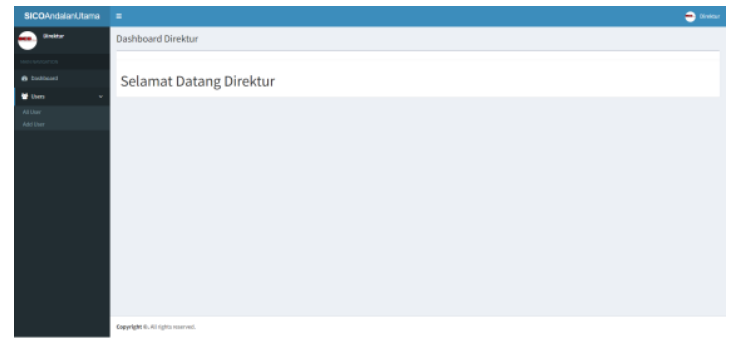

Gambar 11. Antarmuka Halaman Menu Direktur

\section{Pengujian}

Tahapan ini adalah melakukan implementasi sistem dan pengujian program/aplikasi, berdasarkan modul dan alur kerja program menggunakan metode White box Testing, Black box Testing, dan Usability Testing.

\subsection{Whitebox}

Nidhra, et al (2015) menambahkan Kelebihan White box Testing antara lain untuk menemukan :

1. Kesalahan Logika

2. Ketidaksesuaian Asumsi

3. Kesalahan Pengetikan

Maka dari itu hasil pengujian dari 3 kategori diatas akan dijelaskan berikut ini.
1. Pengujian White Box Login

a. Jumlah region dari graf alur mengacu kepada kompleksitas cyclomatic.

b. Kompleksitas cyclomatic untuk graf alur $\mathrm{G}$ didefinisikan:

$\mathrm{V}(\mathrm{G})=\mathrm{E}-\mathrm{N}+2$

Dimana $\mathrm{E}=$ jumlah edge, dan $\mathrm{N}=$ jumlah node

c. Kompleksitas cyclomatic untuk graf alur $\mathrm{G}$ didefinisikan:

$\mathrm{V}(\mathrm{G})=\mathrm{P}+1$

Dimana $\mathrm{P}=$ jumlah predicates nodes

Dibawah ini tabel 8 merupakan pengujian white box login.

Tabel 8. Pengujian White Box Login

\begin{tabular}{|c|c|}
\hline No & Source Code \\
\hline 1 & $\begin{array}{l}\text { function index() } \\
\text { \$this->form_validation- } \\
\text { set_rules('username','Username','required'); } \\
\text { \$this->form_validation- } \\
\text { set_rules('password','Password','required'); }\end{array}$ \\
\hline 2 & if $($ \$this- $>$ form_validation->run ()$==$ TRUE $) \quad\{$ \\
\hline 3 & $\begin{array}{l}\text { \$s=array('username' }=>\text { \$this->input- } \\
>\text { post('username'),); }\end{array}$ \\
\hline 4 & if $(\$$ this->m_db->is_bof('pengguna',\$s)==FALSE) \\
\hline 5 & $\begin{array}{l}\text { \$s2=array('username'=>\$this->input- } \\
>\text { post('username'), } \\
>\text { post('password')), } ;\end{array}$ \\
\hline 6 & if $($ \$this->m_db->is_bof('pengguna',\$s2)==FALSE) \\
\hline 7 & $\begin{array}{l}\text { \$akses=\$this->m_db- } \\
\text { >get_row('pengguna',\$s2,'akses'); } \\
\text { \$userid=\$this->m_db- } \\
\text { >get_row('pengguna',\$s2,'user_id'); } \\
\text { \$this->session- } \\
\text { >set_userdata('infouser',array('userid'=>\$userid, } \\
\text { 'username'=>\$this->input->post('username'), } \\
\text { 'akses'=>\$akses,)); } \\
\text { redirect(base_url().\$akses.'/dashboard'); }\end{array}$ \\
\hline 8 & \}else \{ \\
\hline 9 & redirect(base_url()); $\}$ \\
\hline 10 & \}else \{ \\
\hline 11 & redirect(base_url()); $\}$ \\
\hline 12 & \}else \{ \\
\hline 13 & $\begin{array}{l}\text { \$meta['judul']="User Login"; } \\
\text { \$this->load->view('tema/loginview',\$meta); \} }\end{array}$ \\
\hline 14 & \} \\
\hline
\end{tabular}

Berdasarkan pengujian white box login berikut flowgraph dari pegujian tersebut pada gambar 12 .

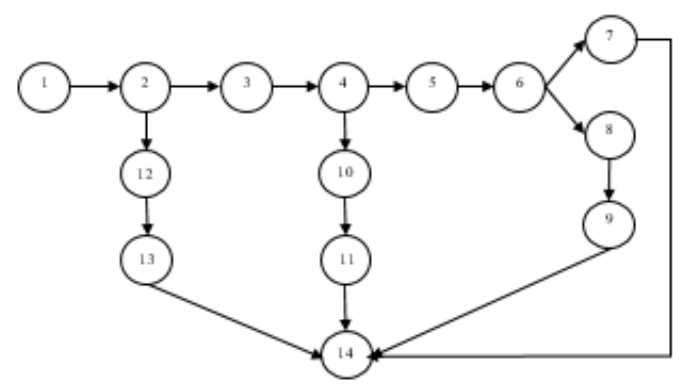

Gambar 12. Flowgraph Login

Dari gambar 12 di atas Flowgraph Login maka diketahui :

Node $(\mathrm{N})=14$ Lingkaran 
Edge (E)

$$
=16 \text { Tanda Panah }
$$

Predicate

$$
=3 \text { kondisi }
$$

Cyclomatic Complexity digunakan untuk mencari jumlah Path dalam suatu flowgraph, dapat dihitung dengan rumus sebagai berikut.

$\mathrm{E}($ edge $)=16$

$\mathrm{N}($ node $)=14$

$\mathrm{V}(\mathrm{G})$

$$
\begin{aligned}
& =\mathrm{E}-\mathrm{N}+2 \\
& =16-14+2 \\
& =4
\end{aligned}
$$

Jadi cyclomatic complexity adalah 4 path (jalur)
a. Path $1: 1-2-12-13-14$
b. Path $2: 1-2-3-4-10-11-14$
c. Path $3: 1-2-3-4-5-6-7-14$
d. Path $4: 1-2-3-4-5-6-7-8-9-14$

\subsection{Blackbox}

Pada sistem pendukung keputusan kelayakan klaim asuransi ini juga menggunakan pengujian Black Box. Dengan Teknik ini ditemukan beberapa hal-hal berikut:

1. Fungsi yang tidak benar atau tidak ada.

2. Kesalahan antarmuka (interface errors).

3. Kesalahan pada struktur data dan akses basis data.

4. Kesalahan performansi (performance errors).

5. Kesalahan inisialisasi dan terminasi.

\subsection{Usability Testing}

Tujuan usability testing adalah sejauh mana suatu produk dapat digunakan oleh pengguna tertentu untuk mencapai target yang ditetapkan dengan efektivitas, efesiensi dan mencapai kepuasan penggunaan dalam konteks tertentu.

Adapun cara menjawab pertanyaan dengan Menentukan bobot penilaian untuk setiap pilihan antara lain, Sangat Tidak Setuju (STS) bernilai 1, Tidak Setuju (TS) bernilai 2, Cukup (C) bernilai 3, Setuju (S) bernilai 4 dan Sangat Setuju (SS) bernilai 5. Penentuan nilai ini ditentukan berdasarkan skala Likert.

Seluruh responden mengisi skor untuk setiap jawaban yang diberikan dengan skala 1 sampai 5 . Kolom responden menunjukkan responden 1 sampai responden ke-6 yang ditandai dengan nomor urut, sedangkan kolom X1 sampai X10 menunjukkan skor dari setiap pertanyaan yang diberikan oleh responden. Kolom X1 menunjukkan pertanyaan ke-1, Kolom X2 menunjukkan pertanyaan ke-2, begitu seterusnya sampai kolom X10 menunjukkan pertanyaan ke-10. Adapun rekap hasil skor dari seluruh responden dapat dilihat pada tabel 10 dibawah:

Tabel 10. Hasil Tabulasi skor tiap pertanyaan SUS

\begin{tabular}{|c|c|c|c|c|c|c|c|c|c|c|}
\hline Res & $\mathrm{X}$ & $\mathrm{X}$ & $\mathrm{X}$ & $\mathrm{X}$ & $\mathrm{X}$ & $\mathrm{X}$ & $\mathrm{X}$ & $\mathrm{X}$ & $\mathrm{X}$ & $\mathrm{X} 1$ \\
$\mathrm{p}$ & 1 & 2 & 3 & 4 & 5 & 6 & 7 & 8 & 9 & 0 \\
\hline 1 & 4 & 2 & 4 & 4 & 4 & 2 & 4 & 2 & 5 & 3 \\
\hline 2 & 5 & 1 & 5 & 3 & 5 & 2 & 5 & 1 & 5 & 3 \\
\hline 3 & 4 & 3 & 4 & 3 & 4 & 2 & 4 & 2 & 4 & 3 \\
\hline 4 & 5 & 3 & 3 & 4 & 3 & 3 & 3 & 3 & 3 & 3 \\
\hline 5 & 5 & 2 & 5 & 2 & 5 & 2 & 5 & 1 & 5 & 2 \\
\hline 6 & 4 & 3 & 2 & 4 & 3 & 3 & 4 & 4 & 4 & 4 \\
\hline
\end{tabular}

Setelah melakukan proses perhitungan skor SUS. Dari 6 responden yang melakukan proses

\begin{tabular}{|c|c|c|c|c|c|c|c|c|c|c|c|}
\hline Res & $\bar{X}$ & $\mathrm{X}$ & $\mathrm{X}$ & $\mathrm{X}$ & $\mathrm{X}$ & $\mathrm{X}$ & $X$ & $\mathrm{X}$ & $\mathrm{X}$ & $\mathrm{X} 1$ & Sko \\
\hline $\mathrm{p}$ & 1 & 2 & 3 & 4 & 5 & 6 & 7 & 8 & 9 & 0 & $\mathrm{r}$ \\
\hline 1 & $\begin{array}{l}7, \\
5\end{array}$ & $\begin{array}{l}7, \\
5\end{array}$ & $\begin{array}{l}7, \\
5\end{array}$ & $\begin{array}{l}2, \\
5\end{array}$ & $\begin{array}{l}7, \\
5\end{array}$ & $\begin{array}{l}7, \\
5\end{array}$ & $\begin{array}{l}7, \\
5 \\
\end{array}$ & $\begin{array}{l}7, \\
5\end{array}$ & 10 & 5 & 71 \\
\hline 2 & $\begin{array}{l}1 \\
0 \\
\end{array}$ & $\begin{array}{l}1 \\
0\end{array}$ & 10 & 5 & 10 & $\begin{array}{c}7, \\
5\end{array}$ & 10 & 10 & 10 & 5 & 89,5 \\
\hline 3 & $\begin{array}{l}7, \\
5 \\
\end{array}$ & 5 & $\begin{array}{l}7, \\
5 \\
\end{array}$ & 5 & $\begin{array}{l}7, \\
5 \\
\end{array}$ & $\begin{array}{l}7, \\
5 \\
\end{array}$ & $\begin{array}{l}7, \\
5 \\
\end{array}$ & $\begin{array}{l}7, \\
5 \\
\end{array}$ & $\begin{array}{l}7, \\
4 \\
\end{array}$ & 5 & 67,4 \\
\hline 4 & $\begin{array}{l}1 \\
0\end{array}$ & 5 & 5 & $\begin{array}{c}2, \\
5\end{array}$ & 5 & 5 & 5 & 5 & 5 & 5 & 52,5 \\
\hline 5 & $\begin{array}{l}1 \\
0\end{array}$ & $\begin{array}{l}7, \\
5\end{array}$ & 10 & $\begin{array}{l}7, \\
5\end{array}$ & 10 & $\begin{array}{l}7, \\
5\end{array}$ & 10 & 10 & 10 & 7,5 & 90 \\
\hline 6 & $\begin{array}{l}7, \\
5\end{array}$ & 5 & $\begin{array}{l}2, \\
5\end{array}$ & $\begin{array}{l}2, \\
5\end{array}$ & 5 & 5 & $\begin{array}{l}7, \\
5\end{array}$ & $\begin{array}{l}2, \\
5\end{array}$ & $\begin{array}{l}7, \\
5\end{array}$ & 2,5 & 47,5 \\
\hline \multicolumn{11}{|c|}{ Total } & $\begin{array}{c}69,6 \\
5 \\
\end{array}$ \\
\hline
\end{tabular}
perekaman dan pengisian kuesioner didapatkan nilai skor SUS berdasarkan perhitungan sebelumnya, akan ditampilkan pada tabel 11 sebagai berikut :

Tabel 11. Tabel Skor Akhir SUS

Menurut Hilda dalam Bangor et al (2018) Skor SU dianalisis dan diinterpretasikan menggunakan kategori penerimaan (acceptability), skala nilai, dan adjective rating dengan skala kelipatan 10. Skala 1 $>10$ masuk ke dalam rating worst imaginable, skor $>10$ - 20 masuk ke dalam rating awful, skor 20 - >30 masuk ke dalam rating poor, skor $>30$ - >50 masuk ke dalam rating $o k$, skala $>50$ - $>70$ masuk ke dalam rating good, skala $>70->80$ masuk ke dalam rating excellent, sedangkan skala $>80$ sampai $>90$ masuk ke dalam rating best imaginable yang ditunjukkan pada gambar 13 dibawah:

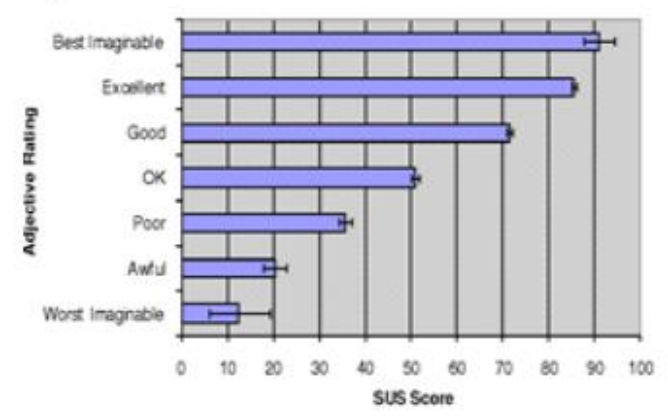

Gambar 13. Rating dan Nilai SUS

Sedangkan untuk menentukan grade scale skala yang digunakan adalah 0 - 60 untuk grade scale $\mathrm{F}$, $>60$ - 70 untuk grade scale $\mathrm{D},>70$ - 80 untuk grade scale $\mathrm{C},>80$ - 90 untuk grade scale $\mathrm{B}$, dan >90 - 100 untuk grade scale A. Sedangkan untuk acceptability ranges menggunakan skala $0-60$ untuk not acceptable dan >60 - 100 untuk acceptable yang ditunjukkan pada gambar 14 dibawah:

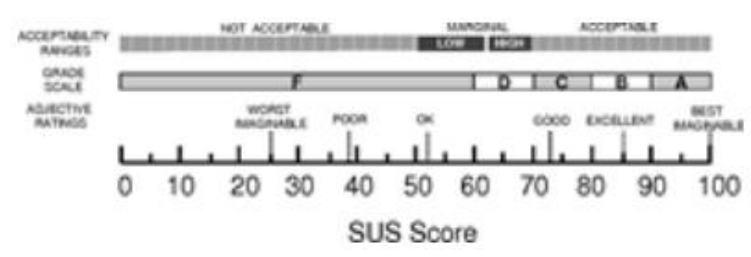

Gambar 14. Grade Scale \& Acceptability Ranges SUS

Berdasarkan pengolahan data seperti yang ditabulasikan pada Tabel 11 diperoleh skor SUS 
sebesar 69,65, yang berarti bernilai D jika dikonversikan menurut standar Menurut Hilda R. Dan Siti N. dalam Bangor dkk (2018), dan masuk dalam kategori Acceptable jika dikonversikan menurut kisaran rating penerimaan. Dengan demikian, maka Sistem Pendukung Keputusan Kelayakan Klaim memiliki usability Good menurut para responden.

\section{Kesimpulan}

Kesimpulan yang dapat diambil dari penelitian setelah menyelesaikan pengujian yaitu dihasilkan Sistem Pendukung Keputusan Berbasis Web untuk kelayakan klaim asuransi dalam hal ini dibatasi asuransi jenis Surety Bond yang diajukan nasabah menggunakan model Analytical Hierarchy Process (AHP) berdasarkan kriteria, sistem dapat membantu perusahaan dalam pengambilan keputusan kelayakan klaim yang diajukan nasabah lebih akurat dan membutuhkan waktu singkat.

Penelitian tentang sistem pendukung keputusan kelayakan klaim asuransi ini masih dalam dibatasi jenis asuransi Surety Bond saja, pengembangan selanjutnya diharapkan bisa menentukan kelayakan klaim jenis asuransi lain dan menggunakan beberapa metode atau model sistem pendukung keputasan yang lain.

\section{Daftar Pustaka:}

Himawa, D. (2019). Analisis Perbandigan Menggunakan Metode AHP, TOPSIS, dan SAW Dalam Studi Kasus Sistem Pendukung Keputusan Peminjam Yang Bagi Lembaga Keuangan (SKIPRSI). Retrieved from Repositori Institusi Universitas Sumatera Utara (RI-USU) Database. (USU No. 13881)

Rachmi, H. \& Nurwahyuni, S. (2018). Pengujian Usability Lokamedia Website Menggunakan System Usability Scale. AL-KHIDMAH 1, 86-92.

Adrian, Q. J. \& Destiningrum, M. (2017). SISTEM INFORMASI PENJADWALAN DOKTER BERBASSIS WEB DENGAN MENGGUNAKAN FRAMEWORK CODEIGNITER (STUDI KASUS: RUMAH SAKIT YUKUM MEDICAL CENTRE) . Jurnal TEKNOINFO, Vol. 11, No. 2, 30-37.

Riyandi, A. O., Dengen, N., \& Islamiyah. (2017). SISTEM PENDUKUNG KEPUTUSAN KELAYAKAN PEMBERIAN BANTUAN DANA ATAU KREDIT UNTUK USAHA KECIL MENENGAH (UKM) PADA BANK NEGARA INDONESIA (BNI) . e-ISSN 25407902 dan p-ISSN 2541-366X Vol. 2, No. 1, , 813.

Aniati, T. E. (2013). Analisis dan Desain Pengembangan Sistem Informasi Akses Jurnal Jurusan Teknik Informatika Universitas Islam Negeri Malang.

Frieyadie. $(2015)$. PENERAPAN RAPID APPLICATION DEVELOPMENT MODEL
PADA PERANCANGAN DAN KAJIAN SISTEM INFORMASI PENJUALAN BERBASIS WEB . JURNAL SISTEM INFORMASI STMIK ANTAR BANGSA VOL. IV NO. 2 , 135-141.

Guntara, D. (2016). ASURANSI DAN KETENTUAN-KETENTUAN HUKUM YANG MENGATURNYA . Jurnal Justisi Ilmu Hukum ISSN 2528-2638 Vol 1, NO 1, 2946.

Keuangan, O. J. (2020, Februari 5). Statistik IKNB. Retrieved from otoritas jasa keuangan: https://ojk.go.id/id/kanal/iknb/data-danstatistik/statistik-iknb/Pages/Statistik-IKNBPeriode-Desember-2019.aspx

Nahdhatuzzahra, I. B. (2016). PENERAPAN USABILITY TESTING TERHADAP SISTEM INFORMASI PENYEBARAN PENYAKIT UNGGAS. Kumpulan Jurnal Ilmu Komputer (KLIK) Volume 03 No.02, 182194.

Randi, V. \& Palit., Y. D. (2015). Rancangan Sistem Informasi Keuangan Gereja Berbasis Web Di Jemaat GMIM Bukit Moria Malalayang . EJournal Teknik Elektro dan Komputer vol. 4 no. $7,1-7$.

Sophian. (2013). Web Design HTML, CSS, dan Javascript.

Suryono, S. A. (2017). ANALISIS PERMASALAHAN PENCAIRAN KLAIM SURETY BOND AKIBAT PRINCIPAL YANG WANPRESTASI PADA PERJANJIAN PEMBORONGAN BANGUNAN SEBAGAI JAMINAN YANG DIKELUARKAN OLEH PERUSAHAAN ASURANSI (Studi di PT (Persero) Asuransi Kredit Indonesia Cabang Madura). Privat Law Vol. V No 2 , 53-60.

Kosasi, S. \& Yuliani, I. D. A. E. (2015). PENERAPAN RAPID APPLICATION DEVELOPMENT PADA SISTEM PENJUALAN SEPEDA ONLINE . Jurnal SIMETRIS, Vol 6 No 1 , 27-36.

Yustanti, D. L. (2016). RANCANG BANGUN E VOTING BERBASIS WEBSITE DI UNIVERSITAS NEGERI SURABAYA . Jurnal Manajemen Informatika. Volume 6 Nomor 1, 72-81.

Prasetyo, B., Pattiasina T. J., \& Soetarmono, A. N. (2015). Perancangan dan Pembuatan Sistem Informasi Gudang (Studi Kasus : PT. PLN (Persero) Area Surabaya Barat) . TEKNIKA Volume.4 Nomor 1, 12-16.

Sari, D. R., Windarto, A. P., Hartama, D. \& Solikhun (2018). Sistem Pendukung Keputusan untuk Rekomendasi Kelulusan Sidang Skripsi Menggunakan Metode AHP-TOPSIS. Jurnal Teknologi dan Sistem Komputer, 6(1), , 1-6 